\title{
The Influence of Training on Business Performance of Women Entrepreneurs: The Mediating Role of Innovation
}

\author{
Rahmat Magajiya Aliyu, Tunku Salha Tunku Ahmad*, Norshahrizan Nordin \\ School of Business innovation and Technopreneurship, Universiti Malaysia Perlis, 01000 UniMAP, Kangar, Malaysia
}

*Corresponding author: salha@unimap.edu.my

Article history: Received 25 February 2019 Received in revised form: 05 April 2019 Accepted: 28 May 2019 Published online: 29 August 2019

\begin{abstract}
This study examined the effect of Training (TR) on the Business Performance (BP) of women in Nigeria using Innovation (I) as a mediator in order to improve the business performance of women which in the long-run contribute positively towards the increase of the Nigerian GDP. Data required for the study was collected from the Women Micro, Small and Medium Enterprises (MSMEs) operating in the North-Western States of Nigeria using a survey design and stratified disproportionate sampling. A designed questionnaire has been distributed across the target population of 576 respondents through selfadministration. In order to evaluate the proposed data, the study has adopted the Partial Least Squares-Structural Equation Modelling (PLS-SEM). The findings revealed that the mediating effect of Innovation on Training is an important strategic element for the enhancement of business performance among women in the MSMEs in Nigeria. The findings also revealed that the business performance of women in the MSMEs depends on the degree of Training that the women attend. Innovation was found to mediate the effects between Training and Business Performance of women. The findings of this study have provided important insights to women owners/managers of the MSMEs, policy makers and researchers to further understand the effects of Training on Innovation and the Business Performance of women in the MSMEs. Thus, women should also be encouraged to improve their Training on Innovation which may increase their business performance.
\end{abstract}

Keywords: Training; innovation; women business performance; micro small and medium enterprises.

\begin{abstract}
Abstrak
Kajian ini mengkaji kesan-kesan latihan terhadap prestasi perniagaan golongan wanita di Nigeria dengan menggunakan inovasi sebagai perantara untuk memperbaiki prestasi perniagaan golongan wanita di mana dalam jangka masa panjang, prestasi perniagaan yang meningkat ini akan menyumbang kepada pertumbuhan KDNK Nigeria. Data yang diperlukan untuk kajian ini diperolehi daripada Perusahaan Mikro, Kecil dan Sederhana yang beroperasi di negerinegeri di bahagian Barat Laut Nigeria dengan menggunakan kaedah tinjauan melalui persampelan rawak sistematik dan berstrata. Borang soalselidik telah diedarkan kepada 576 responden. Bagi menilai data yang telah dikumpulkan, kajian ini menggunakan Model Persamaan Struktur-Penganggaran Kuasa Dua Terkecil Separa (PLS-SEM). Hasil kajian menunjukkan bahawa kesan perantara inovasi terhadap latihan adalah satu elemen strategik yang penting untuk meningkatkan prestasi wanita yang mengusahakan perniagaan mikro, kecil dan sederhana di Nigeria. Hasil kajian juga menunjukkan prestasi wanita dalam perusahaan tersebut bergantung kepada darjah latihan yang dihadiri oleh pengusaha wanita. Inovasi didapati menjadi pemangkin/perantara di antara latihan dan prestasi perniagaan pengusaha wanita yang dikaji. Kajian ini telah memberikan input penting kepada pemilik/pengurus perusahaan mikro, kecil dan sederhana, pembuat dasar dan para penyelidik untuk lebih memahami kesan-kesan latihan dan inovasi terhadap prestasi wanita yang mengusahakan perusahaan mikro, kecil dan sederhana. Mereka harus diberi galakan untuk meningkatkan latihan berkaitan inovasi kerana kedua-dua faktor ini boleh membantu meningkatkan prestasi perniagaan mereka.
\end{abstract}

Kata kunci: Latihan; inovasi; prestasi perniagaan wanita; perusahaan mikro, kecil dan sederhana.

() 2019 Penerbit UTM Press. All rights reserved

\subsection{INTRODUCTION}

The importance of Micro Small and Medium Enterprises in influencing the economic growth and development of a country is recognized all over the world as their performance is unanticipated (Ibrahim \& Rosli, 2016; Ali, Hilman \& Gorondutse, 2017; Gorondutse, Ali, Abubakar \& Naalah, 2017). So far, the levels of SMEs employment and contribution to the nation's Gross Domestic Product (GDP) have indicated a low performance (Naala, Nordin \& Omar, 2017). This has led many researchers and practitioners to give so much attention to their significant contributions to the economic growth and the development in both developing and developed nations (Gorondutse, Ibrahim, Abdullwahab, \& Naalah, 2018; Naala Nordin \& Omar, 2017; Naala, 2016; Eniola, 2014). Women entrepreneurs in the developing countries were found to have a lack of training (Ekpe, Mat \& Razak, 2016), and the entrepreneurial activity is a source of human capital development that plays the role of providing an opportunity for learning, ability, attitudes, and skills to individuals. The impact of training in the developing countries on women entrepreneurs' performance has not been addressed adequately in the literature because most women are facing societal discriminations, poverty, and low educational level attainment (Mtey \& Sulle, 2013; Abdulkadir, 
Umar, Garba, \& Ibrahim, 2012). According to Abdulkadir et al. (2012), training is an important factor in the MSMEs as it provides women entrepreneurs with the abilities and practical experience required for business development.

Literature shows that most of the micro-finance customers are lack of specialized skills in using the microfinance facilities. Therefore, they need training in order to use the microfinance facilities. On the other hand, most women entrepreneurs in the developing countries are lacking of prior business experience that is among the most important factors in ensuring enterprise success (Idris \& Agbim, 2015). Therefore, women entrepreneurs need training in using the microfinance facilities to further strengthen their business experience. Some literature suggested the basic needs of examining the impact of training on women business performance in the developing nations due to their low income and low educational background (Geordis \& Pitelis, 2016; Saks \& Smalley, 2014). Training is linked to education; and women entrepreneurs in the developing nations are found to be less educated if compared to women in the developed nations (Ibru, 2009; Hameed, Hussin, Azeem, Arif \& Basheer, 2017). Previous studies have confirmed that training has a positive and significant impact on business performance (Chinomona, 2013; Saks \& Smalley, 2014; Aragon, Jimenez \& Valle, 2014). However, the utilization of entrepreneurial opportunity is determined by the entrepreneur's level of knowledge or skills acquired and networking through working experience (Idris \& Agbim, 2015).

The present study used innovation as a mediator to probe the effects of training on business performance of women in Nigeria. The condition of the indirect effect (Baron \& Kenny, 1986; Hayes, 2009) of innovation on training and business performance of women in the MSMEs in the North-Western States of Nigeria is justified in this study. This paper is classified into five segments; the introductory part, literature review, while the third and fourth segments include the methodology as well as the result and discussions, and lastly is the conclusion of the study.

\subsection{LITERATURE REVIEW}

Rosli and Mahmood (2013) studied the moderating impacts of human resource management practices and the entrepreneur training on innovation performance of the small and medium enterprises (SMEs) in Malaysia using the sample of 284 SMEs in Malaysia. Data was drawn using questionnaires. The findings indicated that training of entrepreneurs has a strong positive significance influence on firm performance.

Davoudi, Fartash, Venera, Asiya, Rashad, Anna and Zhann (2018) examined the relationship between Intellectual Property Rights and Organizational Performance with the Mediating Role of Open Innovation and a sample of 30 Russia Semnan Science and Technology Park companies. Using questionnaire for data collection and Structural Equation Model for data analysis, findings revealed a significant positive relationship of open innovation on organizational performance, and recommended future study to improve the study by selecting additional contexts i.e. educational, electronic, manufacturing, service, and virtual organizations.

Zhou, Zhou, Feng and Jiang (2017) explored the mediating role of innovation on dynamic capabilities and organization performance. A sample of 204 Chinese firms in China was selected. Data were drawn from a questionnaire and the PLS-SEM for data analysis. Results revealed a significant positive effect of innovation on dynamic capabilities of and organization performance. The researchers suggested future study to expand the scope of the research to various enterprises by improving the measurement of innovation.

Al-sa`di, Abdallah and Dahiyat (2017) examined the mediating role of process and product innovation on the influence of operational performance and knowledge management in the manufacturing companies with a sample of 207 Jordanian companies in Amman using survey questionnaires employing the PLS model for data analysis. The finding revealed a significant positive effect of product and process innovations on the Knowledge Management and Operational Performance.

Sharma, Davcik and Pillai (2016) investigated the influence of Brand Equity on Marketing Performance and Research and Development Expenditure with the mediating role of Product Innovation. They used a sample of 10,282 data of Bureau van Dijk Electronic and ACNielsen Italy's report on household's financial statement of food purchase, and regression was employed for data analysis. Findings showed that the Research and Development Expenditure and Brand Equity have a positive significance influence on Product Innovation and the Marketing Performance, and recommended future researchers to use Product Innovation as a moderator in influencing Research Development Expenditure and Brand Equity of Marketing Performance.

Naala, Nordin and Omar (2017) lead a study on the connection between Innovation Capability and Organizational Performance among the Small Medium Enterprises in North-Western Nigeria using the sample of 280 firms. Data was analyzed using the PLS-SEM; the findings revealed that Innovation Capability is a significant SMEs success factor.

$\mathrm{Lu}$, Zhu and Bao (2015) investigated the mediating role of Innovation on the High-performance human resource management and Organizational Performance in China. A sample of 150 pre-survey Chinese manufacturing industries in Beijing, Changchun, Harbin Shanghai, Shenzhen, and other cities was selected. Data were drawn from questionnaires and the PLS-SEM was employed for data analysis. Results revealed a significant effect of innovation on high-performance of HRM and Organizational Performance. The researchers suggested future study to expand the scope of the research to various enterprises scenarios.

Based on the above findings of the previous research, the following hypotheses and research objectives are suggested for this present study.

\subsection{THEORETICAL FRAMEWORK}

Hypotheses of the Study

$\mathrm{H}_{1}$ Training has a positive and significant influence on women business performance in the North-Western Nigeria. $\mathrm{H}_{2}$ Innovation has a positive and significant influence on women business performance in the North-Western Nigeria. $\mathrm{H}_{3}$ : Innovation mediates the influence of training on women business performance in the North-Western Nigeria. 


\section{Research Objectives}

To examine the influence of training on women business performance in the North-Western Nigeria.

To determine whether innovation mediates the influence of training on women business performance in the North-Western Nigeria.

To investigate the influence of innovation on women business performance in the North-Western Nigeria.

Figure 1 shows the research framework for this present study. Training is the independent variable, business performance of women entrepreneurs is the dependent variable while innovation acts as the mediating variable. According to the research hypotheses and research objectives, innovation is assumed to improve the business performance of women in the MSMEs of the North-Western States of Nigeria. This concept is further explained in Figure 2 below.

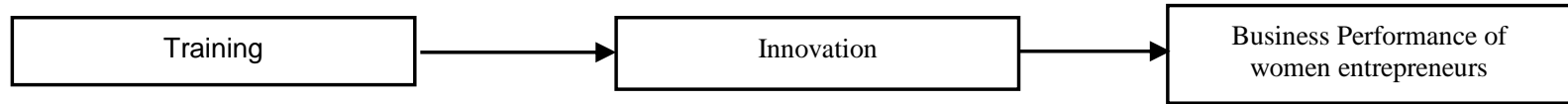

Figure 1 Research framework

This study employed the Resource-Based Theory (RBT) to enhance and support the framework. The RBT encapsulates the focus of the study by taking into consideration the relations among the variables. The focus of the study is primarily on how businesses generate and achieve their performances. In this study, the Resource-Based Theory (RBT) is adopted to explain the relationship between the independent variable (Training), dependent variable (Business Performance of Women in the MSMEs), and the mediating variable (Innovation).

In conformity to the RBT, Training and Innovation are business's resource, which is likely to give a sustainable and outstanding performance to the business, since skill is acquired through experience, which gives different uncommon and unique characteristics to the business strategies. The skill acquisition will allow women entrepreneurs to outperform their competitors.

\subsection{METHODOLOGY}

In this study, the researcher used a quantitative research design. Data required for the study was collected from the Women Micro, Small and Medium Enterprises (MSMEs) operating in the North-Western States of Nigeria using a survey design and stratified disproportionate sampling. A designed questionnaire has been distributed across the target population of 576 respondents through self-administration. The data was analysed using the SPSS (Statistical Package for the Social; Sciences) software and Partial Least Squares-Structural Equation Modelling (PLS-SEM).

\subsection{RESULTS AND DISCUSSION}

Figure 2 shows the result of the data analysis using the Smart-PLS SEM software. This paper measured predictive relevance of the model and the level of R-squared values based on the PLS-SEM result of $20.8 \%$ and $6.9 \%$ of the total variance explained on the independent variable to dependent construct and independent variable to mediator respectively. These findings suggest that Training explained $20.8 \%$ of the variance in the MSMEs performance. Cohen (1988) classified three categories of R-square, 0.02 weak, 0.13 moderate and 0.26 substantial, thus based on the R-squared of this present study, it is found to be moderate and weak respectively.

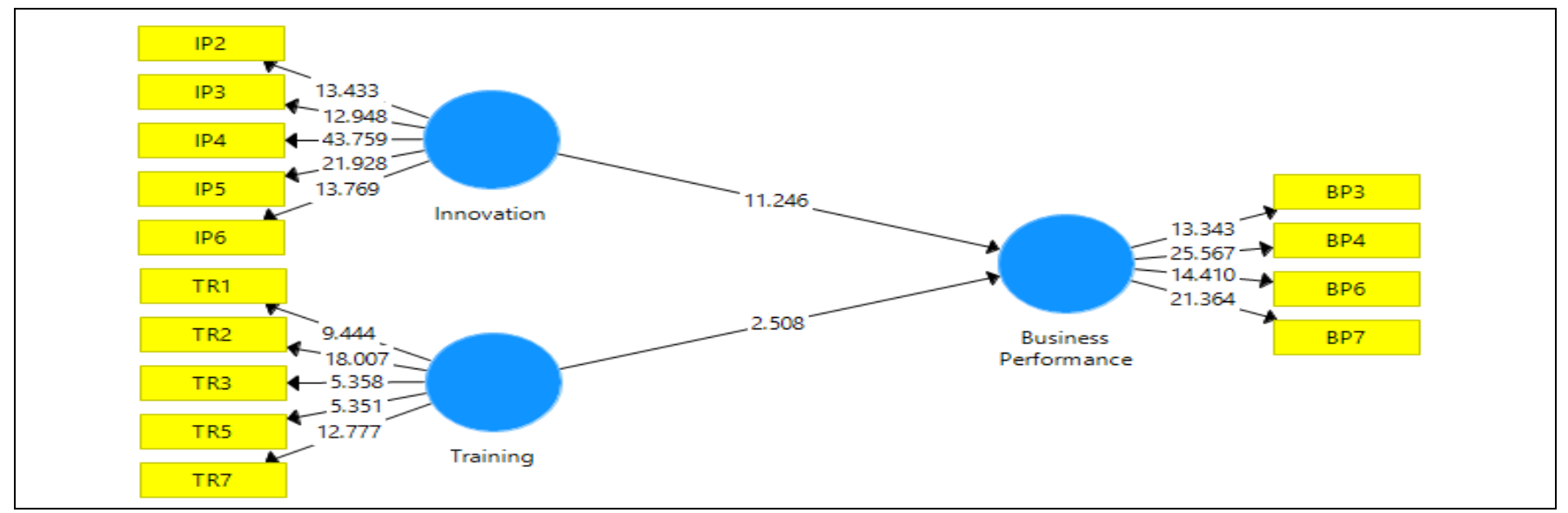

Figure 2 Direct Relationships among training, innovation and business performance of women in the MSMEs in the North-Western States of Nigeria 
Table 1 illustrates the outcomes of the direct relationship between independent (Training) and the dependent variable (Women Business Performance). Hypotheses were examined via Smart-PLS SEM software to determine the direct relationship and the interaction effect (H1 - H2). Statistical model for direct relationship displays the links between Training, Innovation as independent latent variable and Women Business Performance as the dependent latent variable as shown in Figure 3. The findings (as shown in Table 1) revealed that Training has a significant positive effect on Women Business Performance and this finding has supported the first hypothesis $\left(\mathrm{H}_{1}: \beta=0.418\right.$, with $\mathrm{t}$ value; $t=11.246$ ), and this concurs with the past studies (Chinomona, 2013; Sila, 2014; Saks \& Burke-Smalley, 2014; Xayavong, Kingwell, \& Islam, 2016; Georgiadis \& Pitelis, 2016). Similarly, the direct relation of Innovation on Women Business Performance was also tested and finding shows a positive significant effect of Innovation on Women Business Performance. This finding supported the second hypothesis $\left(\mathrm{H}_{2}: \beta=0.113\right.$, with $\mathrm{t}$ value; $\left.t=2.508\right)$. Training will give women entrepreneurs' the abilities to identify and tap the entrepreneurial opportunity and skills, opportunity to acquire knowledge and also to bridge the gap between the current performance and the desired performance which could lead to outstanding business performance.

Table 1 Hypotheses testing of the direct relationship among training, innovation and business performance

\begin{tabular}{lllllll}
\hline Hypothesis & Path & Beta & STDEV & t-value & p-value & Remarks \\
\hline $\mathrm{H}_{1}$ & TR to BP & 0.418 & 0.037 & 11.246 & 0.000 & Accepted \\
$\mathrm{H}_{2}$ & I to BP & 0.113 & 0.045 & 2.508 & 0.000 & Accepted \\
\hline
\end{tabular}

Figure 3 shows the structural model of the mediating relationship of Innovation on Training and Women Business Performance. The finding helps in filling the gap of the literature with regard to the effect/role of Innovation as a mediator between Training and Women Business Performance, specifically in the context of the MSMEs in Nigeria. The results show that Training has an effect on the mediating variable of Innovation, and this in turn influences the dependent variable of Women Business Performance (Hair et al., 2016).

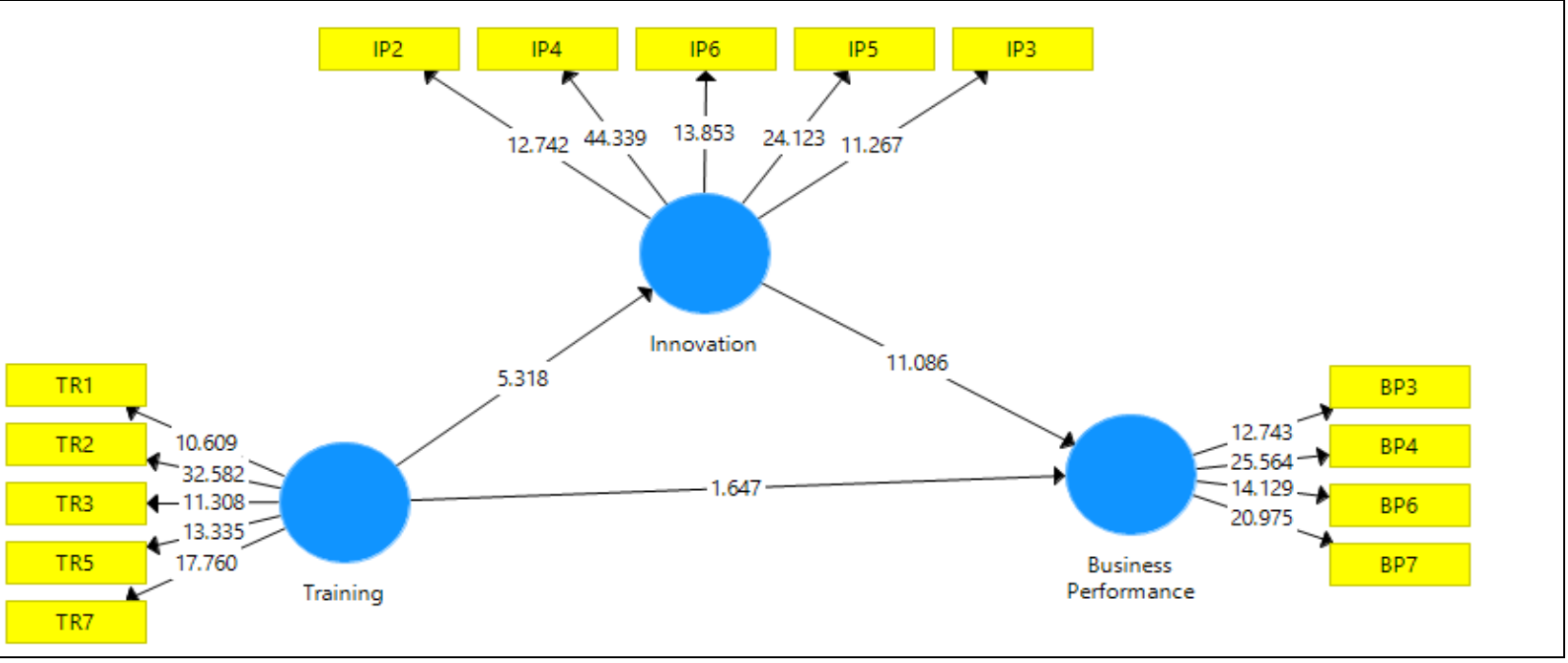

Figure 3 The Mediating effect of innovation

Table 2 indicates the summary of indirect relationship among the variables; Training on Innovation with $\beta=0.111$ and $t$ value, $t=$ 4.548. The finding shows a mediating relationship on the impact of Training on Women Business Performance where innovation serves as the channel of enhancing women business performance. The Nigerian women in the MSMEs whom practice the subordination or team work training are more likely to improve business performance whether directly or indirectly by invoking innovation.

Table 2 Summary of the Mediating Relationship Among Training, Innovation and Women Business Performance

\begin{tabular}{lllllll}
\hline Hypothesis & Path & Beta & STDEV & t-value & p-value & Remarks \\
\hline $\mathrm{H}_{3}$ & TR to I to B P & 0.111 & 0.024 & 4.548 & 0.000 & Accepted \\
\hline
\end{tabular}

Table 3 illustrates the Indicator Loadings and Internal Consistency Reliability of the variables under study. The values of the Average Variance Extracted (AVE) range between 0.500 and 0.554 proposed that the values are acceptable and the AVE square root values are all above the correlations among the reflective latent constructs, which suggest acceptable discriminant validity. The construct validity factor 
determines whether or not the variables been measured are truly measuring the right quantities, based on the grounded theoretical measure, which can be assessed by the means of discriminant validity as well as the convergent validity (Hair, Sarstedt, Ringle, \& Mena, 2012). It was recommended that the composite reliability is more appropriate for the PLS-SEM than the Cronbach's Alpha (Hair et al., 2014). Therefore, the present study uses it for measuring the internal consistency reliability. In this case, the composite reliability coefficient measure of the internal consistency and reliability was assessed and reported in Table 3 below. In this present study, the composite reliability coefficient value ranges from 0.818 to 0.861 which are higher than the value of the minimum level of 0.7 ; this indicates the high level of internal consistency reliability (Hair et al., 2011; Bagozzi \& Yi, 1988). Thus, it can be established that the instruments are reliable.

Table 3 The Indicator loadings and the internal consistency reliability

\begin{tabular}{llllll}
\hline Variables & Indicators & Standardized Loadings & Composite Reliability & AVE & Item(s) deleted \\
\hline Business Performance & BP3 & 0.673 & 0.818 & 0.530 & BP1, BP2, BP5 \\
& BP4 & 0.785 & & & \\
BP6 & 0.690 & & & \\
Innovation. & BP7 & 0.758 & 0.832 & 0.500 & I1 \\
& I2 & 0.637 & & & \\
I3 & 0.620 & & & \\
Training & I4 & 0.823 & & & \\
& I5 & 0.770 & & & \\
& I6 & 0.664 & & & \\
TR1 & 0.713 & 0.554 & & \\
TR2 & 0.846 & & & \\
TR3 & 0.693 & & & \\
TR5 & 0.721 & & & \\
TR7 & 0.740 & & & & \\
\end{tabular}

Table 4 shows the correlations among the reflective latent constructs that indicate acceptable discriminant validity values of 0.707 to 0.744 as suggested by Fornell and Larcker (1981), and Chin's (1998) in which evaluation is done by using the correlations among the constructs with the square roots of AVE.

Table 4 The Discriminant Validity Using the Fornell-Larcker (1981) Criterion

\begin{tabular}{clll}
\hline Latent Variables & BP & I & TR \\
\hline BP & $\mathbf{0 . 7 2 8}$ & & \\
I & 0.448 & $\mathbf{0 . 7 0 7}$ & \\
TR & 0.203 & 0.262 & $\mathbf{0 . 7 4 4}$ \\
Note: BP = Business performance; I = Innovation; TR = Training
\end{tabular}

Table 5 shows all items loadings possessed values. Henseler, Ringle and Sarstedt (2015) criticised the use of both Fornell-Larcker principle and the cross-loadings examinations of the principal methods for discriminant validity evaluation. Furthermore, the authors showed through simulation that these methods do not significantly identify the lack of discriminant validity in a common research situation. This indicates that the proposed model is credible to proceed with the hypotheses testing.

Table 5 The Cross Loadings Values for the Variables Under Study

\begin{tabular}{llll}
\hline Latent Variables & Business Performance & Innovation & Training \\
\hline BP3 & $\mathbf{0 . 6 7 3}$ & 0.225 & 0.210 \\
BP4 & $\mathbf{0 . 7 8 5}$ & 0.399 & 0.206 \\
BP6 & $\mathbf{0 . 6 9 0}$ & 0.245 & 0.142 \\
BP7 & $\mathbf{0 . 7 5 8}$ & 0.382 & 0.049 \\
IP2 & 0.194 & $\mathbf{0 . 6 3 7}$ & 0.121 \\
\hline
\end{tabular}




\begin{tabular}{llll}
\hline IP3 & 0.268 & $\mathbf{0 . 6 2 0}$ & 0.065 \\
IP4 & 0.421 & $\mathbf{0 . 8 2 3}$ & 0.242 \\
IP5 & 0.364 & $\mathbf{0 . 7 7 0}$ & 0.263 \\
IP6 & 0.262 & $\mathbf{0 . 6 6 4}$ & 0.160 \\
TR1 & 0.147 & 0.171 & $\mathbf{0 . 7 1 3}$ \\
TR2 & 0.214 & 0.214 & $\mathbf{0 . 8 4 6}$ \\
TR3 & 0.066 & 0.136 & $\mathbf{0 . 6 9 3}$ \\
TR5 & 0.057 & 0.197 & $\mathbf{0 . 7 2 1}$ \\
TR7 & 0.199 & 0.230 & $\mathbf{0 . 7 4 0}$ \\
\hline
\end{tabular}

\subsection{CONCLUSION}

In conclusion, the business performance of women in the MSMEs located in the North-Western States of Nigeria will remain an important issue and agenda in Nigeria. It is believed that there is a huge opportunity to improve the business performance of women in Nigeria through intensive training that is equipped with appropriate innovation element and capabilities. In the end, the improved business performance will positively and significantly contribute to the nation's economic growth. This study further suggests that future researchers could expand the scope of the study by considering other variables and other regions in Nigeria.

\section{References}

Abdulkadir, F.I., Umar, S., Garba, B.I. \& Ibrahim S.H. (2012). The Impact Of Microfinance Banks On Women Entrepreneurial Development In Kaduna Metropolis Microeconomics and Macroeconomics, 1(3), 28-38.

Al-Sa'di, A. F., Abdallah, A. B., \& Dahiyat, S. E. (2017). The mediating Role Of Product And Process Innovations On The Relationship Between Knowledge Management And Operational Performance In Manufacturing Companies in Jordan. Business Process Management Journal, 23(2), 349-376.

Amadi, B .O. (2012). Perceptions of Capacity Building Among Youths Involved In Vocational Skills Development. Journal of Social and Development Sciences, 3 (6), 214-222.

Aragón, M. I. B., Jiménez, D. J., \& Valle, R. S. (2014). Training And Performance: The Mediating Role Of Organisational Learning. BRQ Business Research Quarterly, 17(3), 161-173.

Barney, J. B. (2014). Gaining and Sustaining Competitive Advantage. Pearson Higher Ed.

Baron, R. M., \& Kenny, D. A. (1986). The Moderator-Mediator Variable Distinction In Social Psychological Research: Conceptual, Strategic, And Statistical Considerations. Journal Of Personality And Social Psychology, 51(6), 1173

Chinomona, R. (2013). Business Owner's Expertise, Employee Skills Training And Business Performance: A Small Business Perspective. Journal of Applied Business Research, 29(6), 1883

Chukwunenye, I. O. \& Igboke, B. N. (2011). Training, Manpower Development And Job Performance: Perception And Relevance Among Civil Servants in Ebonyi State of Nigeria. Journal of Economics and international Finance, 3 (6): 399-406.

Davoudi, S. M. M., Fartash, K., Venera, G. Z., Asiya, M. B., Rashad, A. K., Anna, V. B., \& Zhanna, M. S. (2018). Testing the Mediating Role of Open Innovation on the Relationship between Intellectual Property Rights and Organizational Performance: A Case of Science and Technology Park. EURASIA Journal of Mathematics Science and Technology Education, 14(4), 1359-1369.

Day, G. S. (1999). Market Driven Strategy: Process For Creating Value: With A New Information. Free.

Ekpe, I. Razak, R. C., Ismail, M., \& Abdullah, Z. (2016). Entrepreneurial Skill Acquisition, Psycho-Social Factors And Youth's Self-Employment In Malaysia. Journal of Entrepreneurship Education, 19(2), 93-101.

Falola, H. O., Osibanjo, A. O., \& Ojo, S. I. (2014). Effectiveness of Training And Development On Employees'performance And Organisation Competitiveness In The Nigerian Banking Industry. Bulletin of the Transilvania University of Brasov. Economic Sciences. Series, 7(1), 161

Fornell, C. and Larcker, D.F. (1981), "Evaluating Structural Equation Models With Unobservable Variables And Measurement Error”, Journal of Marketing Research, $18(1), 39-50$

Freel, M., \& De Jong, J. P. (2009). Market Novelty, Competence-Seeking And Innovation Networking. Technovation, 29(12), 873-884.

Georgiadis, A., \& Pitelis, C. N. (2016). The Impact of Employees' and Managers' Training on the Performance of Small-and Medium-Sized Enterprises: Evidence from a Randomized Natural Experiment in the UK Service Sector. British Journal of Industrial Relations, 54(2), 409-421.

Gorondutse, A. H., Ali, R. A., Abubakar, A., \& Naalah, M. N. I. (2017). The Effect Of Working Capital Management On SMEs profitability in Malaysia. Polish Journal of Management Studies, 16.

Gorondutse, A.H., Ibrahim, G., Abdullwahab, H.I. and Naalah, M.N.I., 2018. Founder's Syndrome and Firm Performance of Small and Medium Scale Enterprises in Nigeria. Journal of Health Management and Informatics, 5(1), 1-8.

Grissemann, U., Plank, A., \& Brunner-Sperdin, A. (2013). Enhancing Business Performance Of Hotels: The Role Of Innovation And Customer Orientation. International Journal of Hospitality Management, 33, 347-356.

Hair Jr, J. F., Hult, G. T. M., Ringle, C., \& Sarstedt, M. (2016). A Primer On Partial Leastsquares Structural Equation Modeling (PLS-SEM). Sage Publications.

Hair, J. F., Hult, G. T. M., Ringle, C. M., \& Sarstedt, M. (2017). A Primer on Partial Least Squares Structural Equation Modeling. $2^{\text {nd }}$ Ed. Thousand Oaks: Sage.

Hair, J., Hollingsworth, C. L., Randolph, A. B., \& Chong, A. Y. L. (2017). An Updated And Expanded Assessment Of PLS-SEM In Information Systems Research. Industrial Management \& Data Systems, 117(3), 442-458.

Halim, H. A., Ahmad, N. H., Ramayah, T., \& Hanifah, H. (2014). The Growth Of Innovative Performance Among Smes: Leveraging On Organisational Culture And Innovative Human Capital. Journal of Small Business and Entrepreneurship Development, 2(1), 107-125.

Hameed, W. U., Hussin, T., Azeem, M., Arif, M., \& Basheer, M. F. (2017). Combination of Microcredit And Micro-Training With Mediating Role Of Formal Education: A Micro-Enterprise Success Formula. Journal of Business and Social Review in Emerging Economies, 3(2), 285-291.

Hayes, A. F. (2009). Beyond Baron and Kenny: Statistical Mediation Analysis In The New Millennium. Communication Monographs, 76(4), 408-420.

Henseler, J., Ringle, C. M., \& Sarstedt, M. (2016). Testing Measurement Invariance Of Composites Using Partial Least Squares. International Marketing Review, 33(3), 405-431

Henseler, J., Hubona, G., \& Ray, P. A. (2016). Using PLS Path Modeling In New Technology Research: Updated Guidelines. Industrial management \& data systems, 116(1), 2-20. 
Huhtala, J. P., Sihvonen, A., Frösén, J., Jaakkola, M., \& Tikkanen, H. (2014). Market Orientation, Innovation Capability And Business Performance: Insights From The Global Financial Crisis. Baltic Journal of Management, 9(2), 134-152.

Ibrahim, N., Mahmood, R., \& Bakar, M. (2016). Linking Strategic Improvisation And Entrepreneurial Self-Efficacy To Corporate Entrepreneurship In Nigerian Higher Education Institutions (HEIs). Management Science Letters, 6(12), 742-752.

Lu, K., Zhu, J., \& Bao, H. (2015). High-Performance Human Resource Management And Firm Performance: The Mediating Role Of Innovation in China. Industrial Management \& Data Systems, 115(2), 353-382.

MacKinnon, D. P., Krull, J. L., \& Lockwood, C. M. (2000). Equivalence of the Mediation, Confounding And Suppression Effect. Prevention science, 1(4), 173-181.

Mtey, K. P. F. \& Sulle, A. (2013). The Role Of Education In Poverty Reduction in Tanzania. Global Advanced Research Journal of Educational Research and Review, 2(1), 006-014.

Naala, M. I. N., Nordin, N., \& Omar, W. A. W. (2017). Innovation Capability and Firm Performance Relationship: a Study of Pls-Structural Equation Modeling (PlsSem). International Journal of Organisation \& Business Excellence, 2(1), 39-50.

Penrose, E. T. (1959). The Theory of the Growth of the Firm (1995 ed). New York: John Wiley and Sons.

Peteraf, M. A. (1993). The Cornerstones Of Competitive Advantage: A Resource-Based View. Strategic Management Journal, 14(3), 179-191.

Podsakoff, P. M., \& Organ, D. W. (1986). Self-Reports In Organizational Research: Problems And Prospects. Journal of management, 12 (4), 531-544.

Podsakoff, P. M., MacKenzie, S. B., \& Podsakoff, N. P. (2012). Sources of Method Bias In Social Science Research And Recommendations On How To Control It. Annual Review Of Psychology, 63, 539-569.

Podsakoff, P. M., MacKenzie, S. B., Lee, J. Y., \& Podsakoff, N. P. (2003). Common Method Biases In Behavioral Research: A Critical Review Of The Literature And Recommended Remedies. Journal of applied psychology, 88(5), 879

Porter, M. E. (1981). The Contributions Of Industrial Organisation To Strategic Management. Academy Of Management Review, 6(4), 609-620.

Rosli, M. M., \& Mahmood, R. (2013). Moderating Effects Of Human Resource Management Practices And Entrepreneur Training On Innovation And Small-Medium Firm Performance. Journal of Management and Strategy, 4(2), 60.

Rowland, C. A., Rowland, C. A., Hall, R. D., Hall, R. D., Altarawneh, I., \& Altarawneh, I. (2017). Training and Development: Challenges Of Strategy And Managing Performance In Jordanian Banking. EuroMed Journal of Business, 12(1), 36-51.

Saks, A. M., \& Burke-Smalley, L. A. (2014). Is Transfer Of Training Related To Firm Performance?. International Journal of Training and Development, 18(2), 104115.

Sharma, P., Davcik, N. S., \& Pillai, K. G. (2016). Product Innovation As A Mediator In The Impact Of R\&D Expenditure And Brand Equity On Marketing Performance. Journal of Business Research, 69(12), 5662-5669.

Xayavong, V., Kingwell, R., \& Islam, N. (2016). How Training And Innovation Link To Farm Performance: A Structural Equation Analysis. Australian Journal of Agricultural and Resource Economics, 60(2), 227-242.

Zhou, S. S., Zhou, A. J., Feng, J., \& Jiang, S. (2017). Dynamic Capabilities And Organizational Performance: The Mediating Role Of Innovation. Journal of Management \& Organization, 1-17. 